\title{
MAGÁNÜDÜLŐK ÉPÍTÉSE MAGYARORSZÁGON, KÜLÖNÖS TEKINTETTEL AZ ALFÖLDRE
}

\section{THE BUILT OF LEISURE-TIME PRIVATE HOMES IN HUNGARY WITH SPECIAL REGARD TO THE GREAT HUNGARIAN PLAIN}

\author{
Csordás László ${ }^{1 *}$ \\ ${ }^{1}$ Közgazdaságtan és Jog Tanszék, Gazdaságtudományi Kar, Neumann János Egyetem, Magyarország \\ https://doi.org/10.47833/2020.2.ECO.005
}

\section{Kulcsszavak: \\ turizmus \\ második otthonok \\ szabadidő-lakások építése \\ rendszerváltoztatás}

\section{Keywords:}

tourism

second homes

building of leisure-time homes

transformation of the system

\section{Cikktörténet:}

Beérkezett 2019. szept. 21.

Átdolgozva 2019. okt. 31.

Elfogadva 2019. nov. 20

\begin{abstract}
Összefoglalás
A tanulmány célja, hogy a KSH településsoros adatainak felhasználásával bemutassa az üdülőépítés alakulását Magyarországon országos, megyei és települési szinten évenkénti bontásban 1981-töl napjainkig, valamint - különösen a rendszerváltoztatást megelőző és azt követő időszakban keresse annak okait.

A legtöbb nyaralót 1987-ben alakították ki, ám az azt követö néhány évben a társadalmi-gazdasági változások következtében drámai mértékü csökkenés zajlott. A legtöbb üdülöt 1981 óta Pest, Somogy és Veszprém megyében épitették fel. Településenként vizsgálva a legtöbb nyaralót 1981-90 között Gárdony, Siófok, Balatonkenese, az Alföldön Gyula, Tiszakécske, Békésszentandrás, 1991-töl napjainkig pedig Szentendre, Budapest és Ráckeve, illetve az Alföldön Szolnok, Kiskunmajsa és Békésszentandrás területén alakították ki.
\end{abstract}

\begin{abstract}
The aim of this study is to present the development of building of leisure-time private homes in Hungary at national, county and settlement levels from 1981 up to the present, using the building data of Hungarian Central Statistical Office, looking for reasons in the periods especially before and after the transformation of the system.

Most holiday homes were set up in 1987, but in the following few years there was a dramatic decrease due to socio-economic changes. Since 1981 most of the holiday homes have been built in Pest, Somogy and Veszprém counties. In the settlements' point of view between 1981-1990 the most of the leisure-time private homes were set up in Gárdony, Siófok, and Balatonkenese, in the Great Plain in Gyula, Tiszakécske, Békésszentandrás, since 1991 in Szentendre, Budapest and Ráckeve, in the Great Plain in Szolnok, Kiskunmajsa and Békésszentandrás.
\end{abstract}

\footnotetext{
* Kapcsolattartó szerző. Tel.: +36-76-516-311

E-mail cím: csordas.laszlo@gtk.uni-neumann.hu, csordasl@gmail.com
} 


\section{Bevezetés}

A XX. század utolsó harmadában bekövetkezett gazdasági, társadalmi, technológiai fejlődés jelentős változásokat eredményezett a modern társadalmak életében, melyek érintették az élet szinte minden területét. E struktúraváltás egyik sajátos, az urbanizációval összefüggő jegye, hogy a társadalmi alapfunkciók korábbi kettős tagolódásukat elveszítve időben és térben tovább tagolódtak. A lakó- és munkahelyek mellett egyre nagyobb jelentőségre tettek szert a szabadidő eltöltésének színterei, melynek legfontosabb települési jegyei az üdülö-pihenő térségek térbeli bővülése, és az egyre növekvő szabadidőben használt szabadidő-lakások (üdülök) számának ugrásszerü és tömegméretű emelkedése. A második lakás egy magántulajdonban, vagy tartós használatban lévő ingatlan, amely olyan személy (család) alkalmankénti szállásául szolgál, aki azt nem tekinti állandó lakásának. A szabadidő-lakás egy olyan második otthon, amit túlnyomóan szabadidőben és csak átmenetileg (a napi munkaidő után, a hétvégén, vagy a szabadság ideje alatt) elsősorban szabadidős célokra használnak ([12],[2],[10],[3],[13],[4],[5],[6],[7]).

A második lakás „jelenség” egyik következménye a népesség egyre erősödő hétvégi menekülése a városból, majd egyes rétegek esetében elvándorlás a városkörnyéki településekre. $\mathrm{A}$ második lakások területi elterjedése része a városfejlődési folyamatnak is: a szezonális, vagy egyesek által rekreációs szuburbanizációnak nevezett jelenség egyedi esetekben "valódi" szuburbanizációhoz vezethet [14], azaz a második lakások állandó lakássá alakulnak.

A turizmus, s ezen belül a hazai turizmus évtizedek óta dinamikusan fejlödik. Ugyanakkor nem ismerjük pontosan az üdülésben résztvevők nagyságát, mivel a „hivatalos turizmus” csak a kereskedelmi szálláshelyek forgalmát méri. A KSH a 2001. évi Népszámlálást megelőző összeírása szerint Magyarországon az üdülök összes száma meghaladta a negyedmilliót ([1], [11]), s ezek többségét üdülési célra is használják. A téma jelentőségét leginkább az mutatja, hogy a negyedmillió magyarországi szabadidő-lakásban kialakított férőhelyek (ágyak) száma többszörösét teszi ki a kereskedelmi szállásférőhelyekének, és a belföldiek, de részben a Magyarországot felkereső külföldiek pihenésében évtizedek óta fontos szerepet játszottak/játszanak, ezért a velük való foglalkozás különösen indokolt.

$\mathrm{E}$ tanulmány célja, hogy a KSH adatainak felhasználásával évenkénti bontásban részletesen bemutassa az üdülőépítés alakulását Magyarországon és az Alföldön országos, megyei és települési szinten 1981-töl 2015-ig, valamint keresse annak okait különösen a rendszerváltoztatást megelőző és azt követő időszakban.

\section{Módszer}

A kutatás során a hazai és a nemzetközi szakirodalom tanulmányozásán túl a KSH üdülökkel kapcsolatos adatait vizsgáltam. A fenti adatokat adatbázisba rendeztem, belöle táblázatokat, ábrákat, térképeket szerkesztettem. Alföld alatt - elsősorban statisztikai és lehatárolásbeli megfontolások miatt - a hat alföldi megyét értem.

Az 1970-1980 közötti időszakra csak megyénkénti éves adatok álltak rendelkezésemre, míg 1981-töl az egyes megyék statisztikai évkönyveiböl már az egyes településekre vonatkozó üdülőépítés adatot is ki tudtam gyűjteni, mert az is elérhető volt. Ez jól mutatja a szabadidő-lakások (magánüdülők, nyaralók) akkori jelentőségének növekedését. Az 1990-es évektől a KSH T-STAR adatait elektronikus úton is meg lehet vásárolni, emellett eddig az időpontig (tehát 1990-ig visszamenőleg) a TEIR rendszerében is elérhetők a települési információk, így pl. a lakás- és az üdülőépités adata is. A fentiek miatt a részletesebben vizsgált időszaknak a már települési adatokkal is alátámasztható 1981-2015 közötti éveket választottam, elsősorban azért, mert az üdülőket egyegy településen alakítják ki, hatásaik (előnyeik és hátrányaik) leginkább települési szinten érezhetőek. 


\section{Eredmények}

\subsection{A magánüdülők tömeges elterjedésének okai Magyarországon, és ennek változása a rendszerváltoztatást megelőző és követő időszakban}

Az 1950-es évektöl indult el az üdülési célokat szolgáló második otthonok tömeges elterjedésének harmadik fázisa. Ennek elsődleges oka a motorizáció, a személyi közlekedés általánossá válása, valamint a közlekedési infrastruktúra kiépülése ([12][8][9]), amelynek következtében a távolságok nagymértékben lecsökkentek. Emellett a jólét (magasabb jövedelmek, a személygépkocsik robbanásszerü elterjedése, a háztartásvezetés racionalizálása, technikai feltételeinek javulása), a munkaidő csökkenése, az ötnapos munkahét bevezetése, a tömbben rendelkezésre álló szabadidő növekedése, a fizetett szabadság rendszerének általánossá válása, időtartamának növekedése döntő mértékben hozzájárult e jelenség terjedéséhez. Nem elhanyagolható ugyanakkor az urbanizáció társadalmi, foglalkozási, lakókörnyezeti, pszichés hatása sem, valamint a gyakori infláció, amely igen sok országban arra késztethette az embereket, hogy megtakarított pénzüket a szabadidő eltöltését kellemessé tevő ingatlanok vásárlására fordítsák. Az ökológiai ismeretek terjedése (környezettudat), valamint az emberek azon törekvése, hogy a természetben - a szabad környezetben és ne a városban - pihenjék ki fáradalmaikat, a nosztalgia, a tőkebefektetés, esetleg a spekuláció is szerepet játszhatott a tömegszerűvé válásban ([4][6]).

Bár a nyugati kutatók szerint a második lakások politikai rendszertöl függetlenül mindenhol létrejöttek, a volt szocialista országokban, így hazánkban a fenti okok mellett nem volt elhanyagolható az sem, hogy az 1960-as évektöl a társadalmi struktúraváltás következtében megjelentek az új és arányában bővülő vezetőrétegek, amelyek képviselői a politikai-társadalmigazdasági helyzetböl származó előnyeiket a sajátos presztízst is jelentő magánüdülő megszerzésére fordíthatták. A tőkés országokba való utazási korlátozás (bizonyos időszakokban és eltérő módon), a vállalati és szakszervezeti üdülőkben tapasztalható helyhiány (nem biztosították mindenki számára az évenkénti pihenést), a termőföldek döntő részének kollektivizálása, a gazdasági vállalkozások korlátozásából adódó valamibe való beruházási kényszer hatása is szerepet játszhatott abban, hogy megjelentek az üdülökkel, zártkertekkel kapcsolatos törvények, rendeletek. Lényegében ehhez az időszakhoz, az egyéni (magán) vállalkozásoknak a korábbiaknál nagyobb teret engedő új gazdasági mechanizmus időszakához köthetők a jelentős igényeket részben kielégítő zártkerti és üdülöterületi parcellázások. Az üdülök iránti keresletet tovább növelte az 1970-80-as évek magyar társadalmának eleinte valóságos, majd később látszólagos jóléte. Az engedélyezett második gazdaságban megszerzett jövedelmeket a lakás, az autó megvásárlása után második lakásba, nyaralóba, telekbe, ékszerekbe stb. fektethették [4]. A családok jelentős része rendelkezett valamilyen rekreációt (is) szolgáló telekkel: a falusiak leginkább háztáji és gyümölcsösszőlős kertekkel, a városiak pedig inkább városkörnyéki zártkertekkel és üdülőtelepi nyaralókkal.

Az egész folyamat lendülete kisebb-nagyobb ingadozásokkal egészen az 1980-as évek közepéig tartott. A fordulópont a vizsgált időszak első évtizedében, 1987 után következett be. Részben ekkor vált politikailag is világossá, hogy „nagy a baj”, valamint az is, hogy nyitni kell, s olyan új „reformokat” kellett indítani, amelyröl addig nem volt, nem lehetett szó. A legfontosabbnak az adózási jogszabályok változása, nevezetesen a személyi jövedelemadó és az általános forgalmi adó 1988 januári bevezetése tekinthető. Az emberekben volt valami félelem az újtól, illetve attól, hogy tényleg meg fogják évek múlva vizsgálni, hogy „ki mit szerzett” az 1987. december végi állapot óta. Ennek megfelelően lehetöleg mindenki megpróbálta megoldani a lakás- és üdülőépítését, illetve vásárlását, legalizálni a vagyonelemeket, illetve az áfá-tól való félelem, valamint a felfutóban lévő igen jelentős infláció miatt csökkenteni a költségeket. Jórészt ennek köszönhető, hogy 1987-ben 5206 üdülő épült az országban, amely az azt megelőző és azt követő évekének a másfélszeresét tette ki, s messze a legmagasabb volt az elmúlt 35 évben. Az Alföld 6 megyéjében ugyanebben az évben 871 nyaralót építettek, ami a megelőző évinek több mint kétszeresét érte el.

Az adószabályok mellett azonban domináns szerepet játszott az 1987 utáni visszaesésben az ugyancsak 1987-ben elhatározott és 1988. januárjában bevezetett „világútlevél”, amely nagy lökést adott a hazai lakosság külföldi utazásaihoz, azaz a kiutazó turizmushoz, amely eleinte sajátos módon a bevásárló turizmusban öltött formát. A hazai és azon belül az alföldi dinamikus üdülöépítést 
tehát - a nagy 1987. évi építési csúcs után - hátráltatta a világútlevél 1988. évi bevezetése, amelynek következtében a nem kellöképpen átgondolt hazai devizás vásárlások lehetetlensége miatt megindult Ausztria irányába az ún. Gorenje turizmus. Emellett a gazdasági változásoknak, vállalkozásoknak teret engedő törvények 1988 után lehetővé tették a vállalkozások alapítását, ezen belül is az (eleinte elsősorban autóbuszos kiutazásokra specializálódó) utazási irodák számának rohamos felfutását. Ezek hozzájárultak az üdülési igények változatos, akár egy éven belül több országot is érintő, korábban nem tapasztalt kielégítéséhez is. Megjelentek a tőzsdei cégek is, így a megtakarított pénzek értékmegőrzésének és gyors értéknövelésének már nem az egyik legjelentősebb, legkedveltebb és leghatékonyabb formája volt az ingatlanba, különösen pedig az év nagy részében egyébként is üresen áló üdülőingatlan építésébe való befektetés. A megnyíló lehetőségek következtében egyre többen fogtak vállalkozásokba - a munkahelyek megszünése miatt sokan sajnos kényszerből is -, hogy a rendszerváltoztatást követően kialakuló új élethelyzetüket megoldhassák, így sokan ennek érdekében eladták/feladták korábbi üdülöjüket is.

Összességében megállapítható, hogy az 1980-as évek vége és az 1990-es évek eleje -

a vállalkozások beindulásának már említett folyamata mellett - a gazdaság teljesítőképességének és az életszínvonalnak a visszaesésével, a (szabadon felhasználható) jövedelmek és a szabadidő csökkenésével, a fenntartási és utazási költségek növekedésével, a lakásokra felvett kedvezményes kölcsönök kedvezményes visszafizetésének "befagyasztásával" is jellemezhető, ami egyáltalán nem segítette az üdülők korábban tapasztalt dinamikus építését, sőt annak drasztikus csökkenését hozta. Mindez nyomon követhetö a statisztikai évkönyvekben a csökkenő számú üdülőépítésben, a telekkönyvekben a tulajdonosok gyakoribb cserélődésében, az üdülők "feladásában" is. Az ezredfordulót követően e folyamat folytatódott, bár részben - a lakásépítések állami támogatásának következtében - bizonyos területeken az üdülőként (is) használt lakások számának bővüléséhez vezetett.

\subsection{Az üdülöépítés alakulása országos és alföldi szinten}

Tekintettel arra, hogy az üdülők kialakításának 1981 előtti időszakára nem rendelkezem települési adatokkal, így a teljes időszakra vonatkozó bemutatást országos, megyei és települési szinten végeztem el, országos viszonyításként azonban a vizsgált időszakot megelőző éveket is ábrázoltam. A Magyarországon 1970-2015 között felépített üdülők száma a KSH adatai szerint 102,2 ezer, ennek közel 40 \%-át 1970-80 között építették fel, míg 1981-2015 között alig több mint 63 ezret. Az Alföldön ugyanilyen arányok mutathatók ki: a 10 ezer üdülöből 4,2 ezret alakítottak ki az 197080 közötti időszakban.

Megfigyelhető, hogy a vizsgált időszakot megelőző évben, 1980-ban Magyarországon még csak alig 3 ezer nyaralót létesítettek, és 1981-ben ehhez képest egy év alatt közel 50\%-kal növekedett az épített üdülök száma. Az Alföldön ennél kisebb, csak alig több mint $22 \%$-os volt a bővülés.

Az évenkénti kialakítás vizsgálata alapján két markáns szakasz különíthető el: 1980-1988 között mindegyik évben meghaladta a 3 ezret, azóta viszont elmarad ettöl. Az első szakasz is több időszakra osztható: 1981-84 között felülmúlta a 4 ezret, 1987-ben - elsősorban a következő évben bevezetésre került adójogszabályok változásának köszönhetöen - elérte az 5.206-ot, míg a közte lévő időszakok kisebb visszaesései a gazdaság részbeni megtorpanásaihoz kapcsolódnak (1. ábra). 


\section{1. ábra: Az üdülőépítés évenkénti alakulása Magyarországon, 1980-2015}

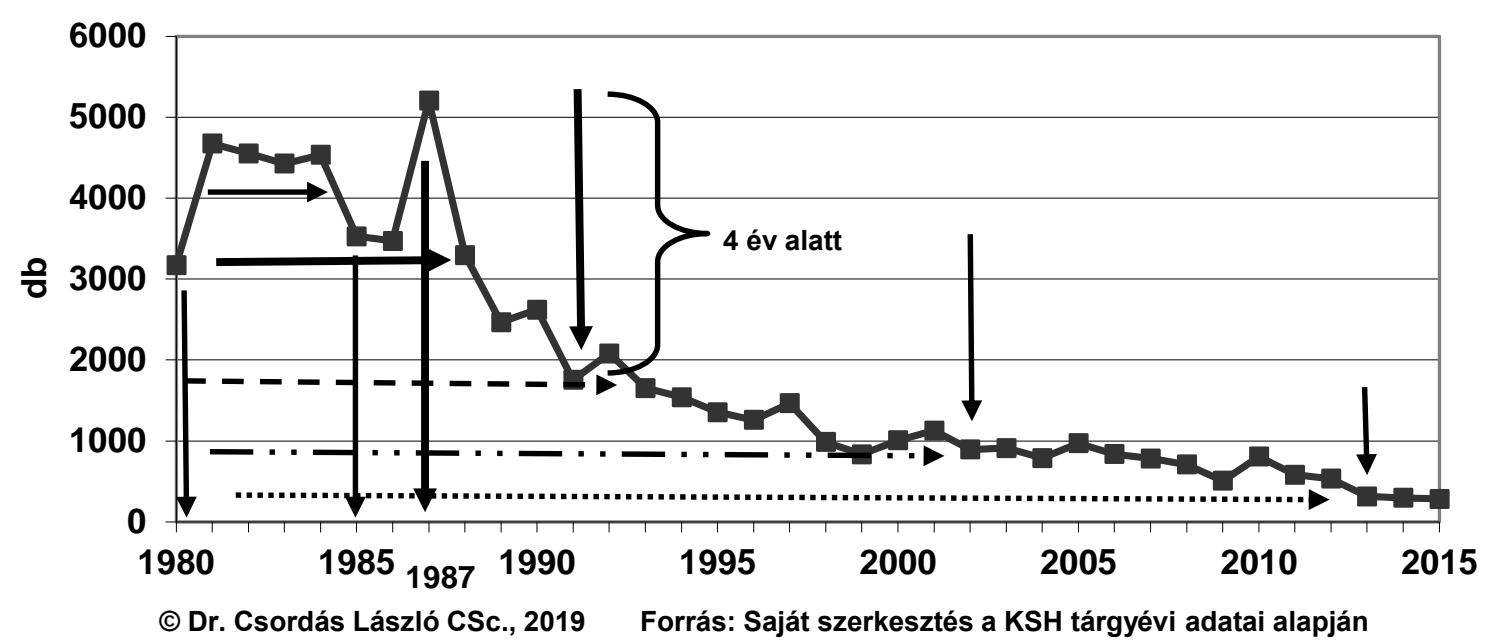

1.ábra: Az üdülőépités évenkénti alakulása Magyarországon, 1980-2015 Forrás: Saját szerkesztés a KSH tárgyévi adatai alapján

Az 1988 óta tartó időszakban - a korábban leírt okok miatt - drámai mértékben csökkent az épített üdülők száma, amit jelez az is, hogy négy év (1987-1991) alatt alig több mint egyharmadára esett vissza az új üdülők kialakítása: első lépcsőben 1988-ra történt egy 37\%-os, majd utána egy közel 25\%-os és 1990-röl 1991-re egy újabb eröteljes 34\%-os visszaesés. Ezt csak tetézi, hogy 1993-tól kezdődően egyetlen évben sem haladta meg az újonnan épített nyaralók száma a 2 ezer darabot, s 1998 óta - 2000-2001 kivételével - már az ezret sem. Az igazi mélypontot 2012 után érte el, azóta ugyanis évente 300 körüli új üdülőépületet létesítettek, a legkevesebbet, 282 darabot éppen 2015-ben. Ez azt jelenti, hogy az 1981. évi induláshoz képest 2015-re kevesebb, mint egytizedére esett vissza az évente felépített nyaralók száma.

Az Alföldön kialakított üdülők száma a 80-as években - 1987 előtt - 389-548 között változott, az országon belüli részesedése 8-16\% közötti volt, legmagasabb értékét az országos trendnek megfelelően éppen 1987-ben érte el, amikor 871 nyaralót építettek fel, ami a megelőző évinek több mint 2,14-szorosát tette ki. Az Alföldön 1987-röl 1988-ra az országosnál is drasztikusabb mértékű (közel 40\%-os) volt a visszaesés (871-ről 526-ra) különösen Békés és Bács-Kiskun megyék miatt, amelyekben 1986-ról 1987-re több mint 2,5-szeresére ugrott a felépített üdülök száma, tehát a visszaesés egy érthető korrekciónak tekinthető. Az országos tendenciákkal ellentétesen ugyanakkor egy visszaerősödés is elindult, amelyben elsősorban Szabolcs-Szatmár-Bereg megye játszott szerepet, ahol éppen 1988-ban és 1989-ben építették fel a legtöbb üdülőt. Szolnok megyében (akkor még így hívták) éppen az időszak végén, 1989-ben és 1990-ben alakítottak ki egyre több második otthont, melynek következtében még 1990-ben is 591 nyaraló építését tudták befejezni az Alföldön, ami akkor az országos érték 22,5\%-át tette ki, messze a legmagasabbat az 1970-1989 közötti időszak korábbi értékeihez képest. Kimutatható ugyanakkor az is, hogy a visszaesés 1990-röl 1991re még az országos átlagnál (34\%) is sokkal jelentősebb, 44\%-os mértékü volt, így 1990-et követően az Alföldön már soha nem érte el a 400 feletti értéket a kialakított üdülök száma:1991-93 között több mint 300, azt követöen csak 2-300 nyaralóépületet húztak fel, de 2000-re már ez is 200 alá süllyedt. Jelentősebb, 25\%-os emelkedés a Széchenyi-terv egyetlen teljes éves időszakához (2001) kapcsolódik, amikor a lakásépítés mellett az üdülőépítés is felfutott és utána még 2004-ig a kritikus 200-as szint körül stabilizálódott. Ezt követően fokozatos csökkenés mutatható ki, 2009-2012-re már csak 100 nyaralót építettek, 2013 után pedig még ez is mérséklődött, így 2015-ben alig 52 darabot üdülöt húztak fel, ami az országos trendnek megfelelően az 1981. évi érték egytizedét sem érte el. 


\subsection{Az üdülőépítések megyénkénti alakulása Magyarországon és az Alföldön 1981-2015 között}

Megyénként vizsgálva megállapítható, hogy Magyarországon a legtöbb üdülőt 1981-2015 között Pest megyében építették fel $(17.410 \mathrm{db})$, a második-harmadik helyre Somogy és Veszprém megye került (7,6, ill. 7,2 ezer), és a 3 megye együttes részesedése meghaladja az összes kialakított nyaralóépület 51 százalékát. Öket a Velencei-tavat övező és Duna-parttal is rendelkező Fejér (4,6 ezer), majd jelentősen lemaradva Zala (2,6 ezer), a három alföldi, Bács-Kiskun, Békés, JászNagykun-Szolnok (2,2-2,2 ezer), valamint Baranya megye követi (2 ezer üdülöépülettel), míg ezernél is kevesebbet csupán Budapesten (843 db) és Csongrád megyében (794 db) létesítettek. Megfigyelhető tehát, hogy az alföldi megyék csak a középmezőnyben, vagy a lista végén találhatók.

Az 1990 óta tartó időszakban mindegyik megyében csökkent a felépített nyaralók száma. Nagyobb időtávot is vizsgálva megfigyelhető a súlypont eltolódása: míg az 1970-es években még a Somogy és Veszprém megyében húzták fel a legtöbb üdülőt, addig 1980 után egyértelmüen Pest megyében, de 1987-ben még Fejér megye is megelözte a már említett két Balaton melletti megyét.

Különösen igaz ez az eltolódás az Alföldre, hiszen az 1970-es években Bács-Kiskun megyében több nyaraló (2,5 ezer) épült mint a többi alföldi megyében együttvéve, sőt annál is több, mint amit Bács-Kiskunban az utóbbi 35 évben, 1981 óta kialakítottak. Az évenkénti és különösen az ötévenkénti összesítések azt mutatják, hogy az 1980-as évek első felében még Bács-Kiskunban, a második felében Békésben, az 1990-es évek első felében és az ezredforduló óta már Jász-NagykunSzolnokban építették fel a legtöbb üdülöt (2. ábra).

2. ábra: Az üdülőépítés évenkénti alakulása az alföldi megyékben, 1980-2015

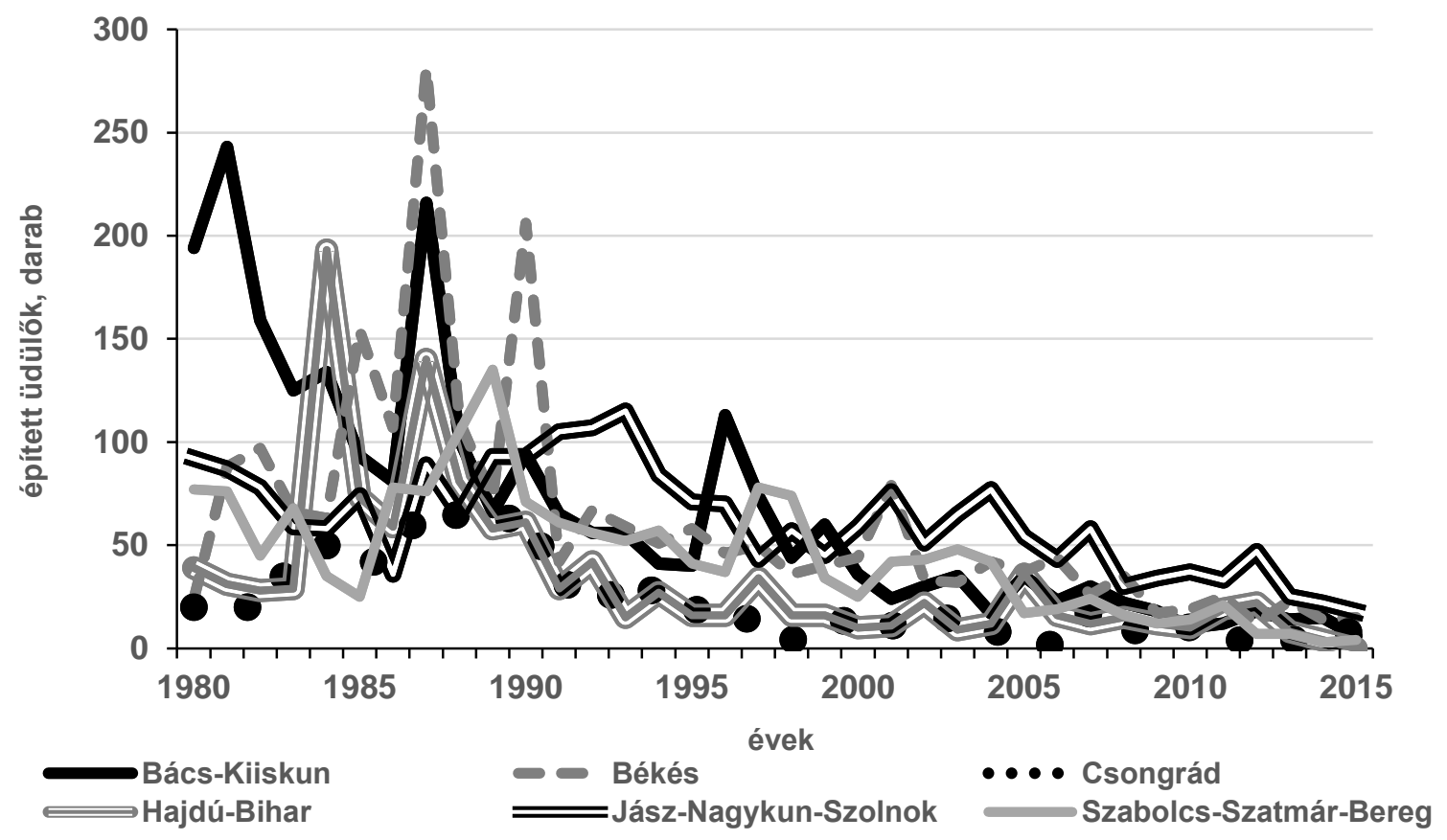

(c) Dr. Csordás László CSc., 2019 Forrás: Saját szerkesztés a KSH tárgyévi adatai alapján

2. ábra: Az üdülőépítés évenkénti alakulása az alföldi megyékben, 1980-2015 Forrás: Saját szerkesztés a KSH tárgyévi adatai alapján

Az 1980-as évek föbb jellegzetessége, hogy erőre kapott a Balaton nyugati partja mentén Zala megye, valamint a Velencei-tó környezetében Fejér megye (kb. 200, illetve 2-300 nyaraló/év), ennek 
közel 3-4-szeresét éri el a másik két Balaton menti megye (Veszprém és Somogy), míg 5-szörösét Pest megye (1000-1200 db). Utóbbi - ettől az időszaktól kezdve napjainkig - átvette a vezető pozíciót az évente épített üdülök számában. A gazdasági nehézségeket követve 1985-86-ra kisebb megtorpanás következett be, hiszen országosan közel ezerrel kevesebb üdülésre használt épületet húztak fel, mint a 80 -as évek elején. A legjelentősebb volumenű visszaesés immáron Somogy és Veszprém megyét érintette, amelyekben közel felére esett, azaz jó 4-400-zal csökkent az újonnan épített nyaralóépületek száma. A trenddel ellentétesen mozgott ugyanakkor Fejér megye, ahol évrölévre (azaz 1985-86-ban is emelkedve) egyre több üdülöt létesítettek. Ez részben összefügghet azzal is, hogy a székesfehérváriak közül sokan a közeli Velencei-tó partján alakították ki hétvégi házaikat, valamint a fövárosiak az állandó lakóhelyükhöz a Balatonnál közelebb, a Velencei-tó környékén, illetve a Fejér megyéhez tartozó Duna-szakaszon szerettek volna, illetve tudtak telekhez jutni, s azon építkezni.

Ezen okok is hozzájárultak ahhoz, hogy 1987-ben a legtöbb felépített nyaralót (1817 db), s egyben a legnagyobb közel $80 \%$-os évi növekedést Pest megye mutatta fel, de Fejérben is meghaladta a 600-at az üdülés céljára kialakított épületek száma. Emellett sok más megyében is ez az év volt a „mini csúcsra-járatás éve”: a balatoni két fő megye mellett az Alföldön pl. Békésben közel 300, Bács-Kiskunban több mint 200, Hajdú-Biharban pedig 140 üdülőépület készült el, míg Szolnok és Csongrád megyében a nyaralók kialakítása az 1980-1987 közötti időszak legmagasabb értékét éppen 1987-ben érte el.

A gazdasági problémák, a jogszabályi változások és az utazási lehetőségek bővülése a következő évtől egyre inkább éreztették hatásaikat ezen a területen is: két év alatt több mint ezerrel, azaz az 1987. évi érték kevesebb, mint felére, további két év alatt, 1991-re már kevesebb, mint egyharmadára (560 db-ra) esett vissza az újonnan létesített magánüdülök száma Pest megyében. Hasonló arányú csökkenés figyelhető meg Fejérben, Somogyban, míg Veszprémben is alig több mint egyharmadára esett az épített nyaralók száma két év alatt. Országosan 1991-re az 1987. évi érték alig több mint egyharmadára apadt az újonnan kialakított szabadidő-lakások száma, amelynek volumenéért elsősorban Pest megye a „felelős”, megjegyezve, hogy Veszprém és különösen Fejér megyében még ennél is nagyobb arányú volt a visszaesés.

Az alföldi megyék e tekintetben felemásan teljesítettek: Békés megyében, ahol a felfutás 1987ben (1986-hoz képest) több mint 2,5-szeres volt 1988-ra a kiinduló értékre tért vissza az üdülök kialakítása, majd innen 1991-re 60\%-ot csökkent, tehát összesítve 1987-hez képest a hetedére zuhant vissza. Hajdú-Biharban közel egyötödére, Bács-Kiskunban kevesebb, mint az egyharmadára, Csongrád megyében kevesebb, mint a felére csökkent a használatba vett épületek száma. Ezzel ellentétben Szabolcs-Szatmár-Beregben csak közel 20 százalékos volt a visszaesés, de úgy, hogy ott - 1987-hez képest - 1988-ban egy 38\%-os, 1989-ben pedig $76 \%$-os növekedés volt kimutatható, majd 1990-re és 1991-re történt meg a drasztikus visszaesés (feleződés) az 1989. évi értékről. Így az 1987 utáni nagy emelkedés és az 1989 utáni ennél még nagyobb volumenü zuhanás után összességében "csak" egyötödével csökkent az épített nyaralók száma. Szolnok megye más utat járt be, mivel ott csak 1988-ban volt mintegy $27 \%$-os visszaesés, az ezt követő évben már az 1987. évinél is több üdülöt alakítottak ki, ami 1991-re már mintegy 20\%-kal, 1992-ben pedig 28 \%-kal haladta meg a "csúcsévnek" tekinthető 1987. évit.

Ugyan Magyarországon 1992-ben egy kisebb felpattanás következtében még 2000 fölé emelkedett az épített üdülök száma, azóta azonban nem érte el ezt, s folyamatosan csökkent, úgy, hogy 1997-ig, valamint 2000-2001-ben még meghaladta az ezret, míg azóta még azt sem éri el. Az egyes megyék közötti különbségek fokozatosan eltünőben vannak: Pest megye továbbra is őrizte vezető pozícióját, de a korábbiakra jellemző, az első és az őt követő megyék, megyecsoportok közötti 2-3-szoros, majd újabb megyecsoportok újabb 2-3-szoros különbségei már elmaradnak. A vizsgált időszak záró évtizedének kezdetén, 2006-ban Pest megyét Zala, Somogy és Veszprém megyék követték a sorban, s az utóbbi kettőben nem érte el a 100-at sem a nyaralóépítés volumene. A 2006-2015 közötti időszakban Pest megyében 10-böl 7 évben, Somogyban és a fövárosban viszont csak 3-3 évben volt magasabb 100-nál a felépített nyaralók száma és csak 2012-ben előzte meg Somogy megye Pest megyét. Az utolsó 3 évben viszont - amikor országosan is csak kb. 300 nyaralót alakítottak ki - egyik megyében sem érte el a felépített nyaralók száma a százat, de továbbra is Pest megyében létesítették a legtöbbet. 
Az Alföldön 1990 után az évenkénti nyaralóépítés mértéke nem érte el megyénként a 100 darabot, ez alól 1991-1993 között csak Jász-Nagykun-Szolnok, valamint 1996-ban Bács-Kiskun megye jelentett kivételt, és azokban az ötéves periódusokban e megyék vezették az üdülöépítés alföldi rangsorát. Az ezredforduló után egy érezhető csökkenés volt kimutatható szinte mindegyik megyében, hiszen elöbb 50, majd 2008 után 30 alá esett a kialakított szabadidő-lakások száma, amely alól a Tisza és a Tisza-tó miatt még felfutóban lévő Jász-Nagykun-Szolnok megye jelentett kivételt mindkét érték tekintetében. Ettől az időszaktól kezdve a korábbi éllovas Bács-Kiskunt megelözve ebben a megyében alakították ki az alföldi megyék közül a legtöbb nyaralót. A paletta másik végén Csongrád megyét kell kiemelni, ahol 2003 után három év (2007, 2009-2010) kivételével tíz alá került a felépített üdülök száma, míg Szabolcs-Szatmár-Bereg és Hajdú-Bihar megyékben erre csak 2012-töl, illetve 2013-tól került sor.

Az ezredforduló utáni időszakban megfigyelhető ugyanakkor az is, hogy a lakáspolitikai ösztönzések (kedvezmények) következtében sok lakás épült - a szuburbanizációval is jellemezhető agglomerálódó térségekben. Az építés célja és a használat jellege közötti ellentmondásra, a használati váltásra utal azonban az, hogy már a 2001. évi Népszámlálás során összeírt nyaralók között sok a lakás céljára szolgáló (lakott) üdülö, ugyanakkor bizonyos területeken megjelentek az üdülésre használt lakások is. Nem tekinthető véletlennek, hogy ezen funkcionális diszharmónia tömeges méretekben a nagy üdülölétszámmal jellemezhető fővárost, Pest megyét, részben a Velencei-tó környéki településeket, járásokat érinti. Megjegyezhető azonban, hogy a 2001. évi Népszámlálást megelöző üdülö-összeírással kapcsolatban olyan ellentmondások is kiderültek, hogy Debrecenben 2821, funkcióját tekintve üdülést szolgáló épületet írtak össze - mivel a zártkertekben kialakított hétvégi házakat is beszámították -, miközben a KSH évkönyvei szerint ott 1981-2000 között egyetlen üdülőépületet sem építettek.

\subsection{Az üdülöépítés településenkénti alakulása Magyarországon és az Alföldön 1981-2015 között}

A vizsgált időszakban, 1981-2015 között az ország közel 600 településén építettek üdülöket, együttes számuk 63 ezer volt. A legtöbb nyaralót Gárdonyban alakították ki (1584 db), de további 7 helyen haladta meg a nyaralók száma az ezret: Szentendrén (1509 db), Balatonkenesén (1319 db), Siófokon (1288 db), Ráckevén (1170 db), Balatonmáriafürdőn (1106 db), Balatonalmádiban (1102 $\mathrm{db}$ ) és Velencén (1027 db). Ezek mellett 12 olyan település volt, ahol 600-1000 nyaralóépületet hoztak létre, ám ezek között már néhány a korábban említett frekventált idegenforgalmi körzetektöl (Balaton, Velencei-tó, budapesti agglomeráció-Dunakanyar) távolabb is megtalálható (pl. Harkány, Veresegyház, Zalakaros).

Az első 20 közé egyetlen alföldi település sem került be, a legtöbb nyaralót - a gárdonyi érték mindössze $37 \%$-át elérő - Tiszakécskén ( $590 \mathrm{db}$ ), majd Békésszentandráson ( $587 \mathrm{db}$ ), Szolnokon (554 db) és Gyulán (542), illetve Tiszacsegén, Tiszavasváriban, Szegeden építették fel. Az üdülök 1981 utáni kialakítása országosan és alföldi szinten továbbra is elsősorban a természetes vizekhez (tavakhoz: Balaton, Velencei-tó, Tisza-tó; folyókhoz: Duna, Tisza, Körösök), valamint a gyógyvizes településekhez kötödött.

Országosan az első 20 település közül csupán 3 olyan akadt (Budapest, Zalakaros és Sukoró), ahol 1991 utáni negyedszázadban több üdülöt építettek, mint 1981-1990 között, míg az Alföldön ez jellemezte a sok nyaralóépületet kialakító települések közül Szolnokot, Kiskunmajsát, Abádszalókot, Gyomaendrődöt, Orosházát és Vásárosnaményt.

A vizsgált intervallumot két, különböző hosszúságú időszakra osztottam elsősorban a politikai korszakhatár, részben pedig a felépített üdülök száma alapján. Az első szakaszban - amely 1981töl 1990-ig tartott, azaz a rendszerváltoztatás évével zárult - meghaladta a kialakított nyaralók száma a 2400 darabot, és az épületek 61,5\%-ának felépítése köthető hozzá. A második szakaszban - amelyik 1991-től 2015-ig tartott - az épített üdülök száma ettől végig elmaradt, így nem csodálkozhatunk, hogy a teljes időszakban kialakított 63 ezerből csak 24,2 ezret adtak át negyedszázad alatt.

Az első szakaszban az ország 323 településének a területén (minden kilencedik helyen) zajlott nyaralóépítés, amelyeken összesen 38.779 üdülőt, a teljes, 1981-2015 közötti időszakban kialakított második otthonok 61,5\%-át hozták létre. A települési összesítésben Gárdonyt (1171 db) Siófok (805 
db) és Balatonkenese követi (802 db), de a 750-nél több nyaralót létrehozó helységek közé tudott kerülni Szentendre, Balatonalmádi, Velence és Balatonmáriafürdő is. Az alföldi települések messze lemaradtak abszolút értékben és így a rangsorban is, hiszen 1981-1990 között 48 helységben összesen csak 5.233 nyaralót alakítottak ki, ami az országos érték 13,5\%-a volt. Legtöbbet - a gárdonyi érték alig több mint egyharmadát kitevő - Gyulán (400 db), valamint Tiszakécskén (389 db) és Békésszentandráson (299 db) építettek, amellyel az országos rangsorban csak a 22. a 25. és a 36. helyet szerezték meg. Utánuk csak Tiszacsege, Szeged, Tiszavasvári és Nyíregyháza rendelkezett 200 feletti értékkel.

Az 1991-2015 közötti időszakban a Magyarország 573 településén felépített 24.276 nyaralóból a legtöbbet Szentendrén (724 db), Budapesten (647 db), Ráckevén (525 db) alakították ki, és csak ezután következik Balatonkenese $(517 \mathrm{db}$ ) és Siófok (483 db), valamint Gárdony (413 db). A bekapcsolódott települések száma 250-nel nőtt, azaz a hazai településállománynak már közel egyötöde volt részese ennek a folyamatnak. Az Alföldön több mint kétszeresére, 105-re nőtt az ebben az időszakban üdülőépítéssel érintett települések száma, ahol összesen 4.846 nyaralót alakítottak ki. Szolnok került az első helyre $441 \mathrm{db}$ nyaralóépülettel - amely a szentendrei érték 61\%ával éppen Gárdony után következik az országos rangsorban -, amit Kiskunmajsa (301 db), Békésszentandrás ( $288 \mathrm{db}$ ) és Abádszalók ( $244 \mathrm{db}$ ) követ, amellyel országosan a 7., a 13., a 15. és a 19. helyet szerezték meg. Emellett Tiszavasváriban, Szegeden, Tiszacsegén és Tiszakécskén vettek használatba 200-nál több nyaralóépületet. Látható tehát, hogy ebben a negyedszázadban az Alföld pozíciói - a csökkenő üdülőépítés ellenére, vagy éppen annak következtében - javultak, itt épült fel a nyaralók egyötöde, egy település bekerült az első 10, további három pedig az első 20 közé.

Az évenkénti adatok azt mutatják, hogy az 1980-as évek első felében (az 1981-84 közötti időszakban) a legtöbb üdülőt építő települések képzeletbeli dobogóján (első három helyén) csak Balaton-partiak találhatók: 1981-83 között Siófok vezette a sort, 1984-ben viszont Boglárlelle volt az első (Siófok ekkor a 3. lett), míg Zamárdi, Fonyód és Balatonalmádi 2-2 alkalommal került a legjobbak közé. Az évtized közepétöl jelentős változás következett be települési szinten is: egyrészt országosan visszaesett közel ezer darabbal a kialakított üdülőépületek száma 1985-86-ban, másrészt teljesen új szereplők jelentek meg az első három helyen (Harkány, Gárdony és Gyula), azaz a Balatontól távoli megyék jelentősebb, sokszor gyógy- és termálturizmusukról híres települései. Az Alföldön az 1980-as-évek elején más-más települések kerültek az 1-2. helyre. Az időszak elején a Bács-Kiskun megyében fekvő Tiszakécske, valamint Kunfehértó, illetve Soltvadkert emelhető ki, mellettük Nyíregyháza 1981-ben és 1983-ban is bejutott az első három közé. A következő évben, 1984-ben csak Hajdú-Bihar megyében fekvő települések kerültek az alföldi dobogós helyekre (Tiszacsege, Hajdúnánás, Hajdúszoboszló), amelyek együttesen a megyében kialakított nyaralók $7 / 8$ részét tették ki, és ez volt a vizsgált 35 évben az egyetlen, amikor az alföldi megyék közül Hajdú-Biharban húzták fel a legtöbb szabadidö-lakást. Ekkoriban az alföldi települések még a legtöbb üdülőt felépítő első tíz hazai település közé sem jutottak be, hiszen míg az országos rangsorban elöl állóknál a létesített nyaralóépületek száma megközelítette a 200-at, addig az alföldi első helyezetteké 34-68 között alakult. A vizsgált 35 éves időszakban összesen 4 alkalommal sikerült elérni alföldi településnek az egy éven belüli 100 fölötti üdülökialakítást. Ebböl három Gyulához és az 1985-1990 közötti időszakhoz (1985, 1987, 1990) egy pedig Tiszakécskéhez és ugyancsak 1987-hez köthető. Ezzel a Körös-partján fekvő gyógyfürdőjéröl híres város az országos rangsorban rendre a 3., a 6. és a 2., míg a Tisza-partján fekvő város a 8. helyre került. Doboz 1986-ban már másodjára végzett az első helyen az Alföldön, és ugyanebben az évben megjelent Szeged is, amihez 1986-ban a Csongrád megyében felépített üdülöépületek közel fele volt köthető.

A következő évtől (1986-89 között) országosan Gárdony vezette a sort és új településként beléptek a Pest megyeiek (Ráckeve, Szentendre, Szigetmonostor), valamint Tiszavasvári és Sopron is. Míg 1981-ben 172 épített üdülővel kerülhetett Siófok az élre, addig 1987-ben Gárdony 251 épülettel végzett az első helyen, ami a vizsgált 35 éves időszak legmagasabb egy településre jutó egy éven belüli nyaralóépítését jelenti. Ebben az évben a dobogós településeken (Gárdony, Ráckeve, Balatonmáriafürdő) felépített nyaralók száma 562 volt, ami az országos érték közel $11 \%$ át érte el. Az országos tendencia helyi, azaz települési szinten is éreztette hatását 1987 után, ugyanis 1988-tól Gárdonyban is drasztikus visszaesés következett (1988: 132 db, 1989: 110 db), 
sőt a 2. és a 3. helyezett településeken már a 100 darabot sem érte el a létesített üdülök száma. A nyaralók kialakításában országosan az egész évtizedben 200-nál több település volt érintett, csúcspontnak itt is 1987 tekinthetö, amikor 240 helyen építettek üdülöépületeket (1. táblázat, 3-4. ábra).

Az 1990-es években (1991-1998 között) minden egyes évben más-más település vezette a sorrendet (Gárdony, Szentendre, Sukoró, Szigetszentmiklós, Orfü, Kiskunmajsa, Balatonkenese, Várgesztes-Tiszavasvári). A fenti időszakot követően Kiskunmajsa (1999) és Balatonkenese (2000) újra első lett, azaz 5 éven belül kétszer is az élre kerültek. Az 1990-es évek közepén (1993-96 között) a Velencei-tó menti Sukoró is felzárkózott Gárdonyhoz, majd eleinte (1998-99-ben) 3. helyezettként, később 2000-ben és 2003-ban a dobogó tetejére került Ráckeve is.

Az 1990-es években már jóval kevesebb nyaralót építettek az alföldi településeken is: a korábbi 100 fölötti szintröl 20-40 közé visszaeső értékekkel már elsők lehettek az alföldi ranglistán. Kimutatható Szolnok "berobbanása" 1992-1998 között (1997 kivételével), de ennél érdekesebb eset Kiskunmajsáé, ahol a földhivatali adatok alapján az 1990-es évek elején 12 üdülö volt, emellett 250 üdülötelek is rendelkezésre állt. Kandidátusi értekezésemben [4] a klaszteranalízis azt mutatta, hogy a Tisza-tó melletti és a termálfürdős települések is külön-külön kategóriákat képeztek, s ezek alapján már akkor utaltam rá, hogy ezeken a helyeken nő a potenciális lehetőség az üdülöépítés folytatására. Ezek után nem meglepö, hogy Kiskunmajsa 1995-1999 között mindegyik évben az alföldi dobogóra került, s ezen belül 1996-ban és 1999-ben az országos rangsorban is az első lett.

\section{3. ábra: Az üdülõépítés településenkénti alakulása Magyarországon, 1981-1990}

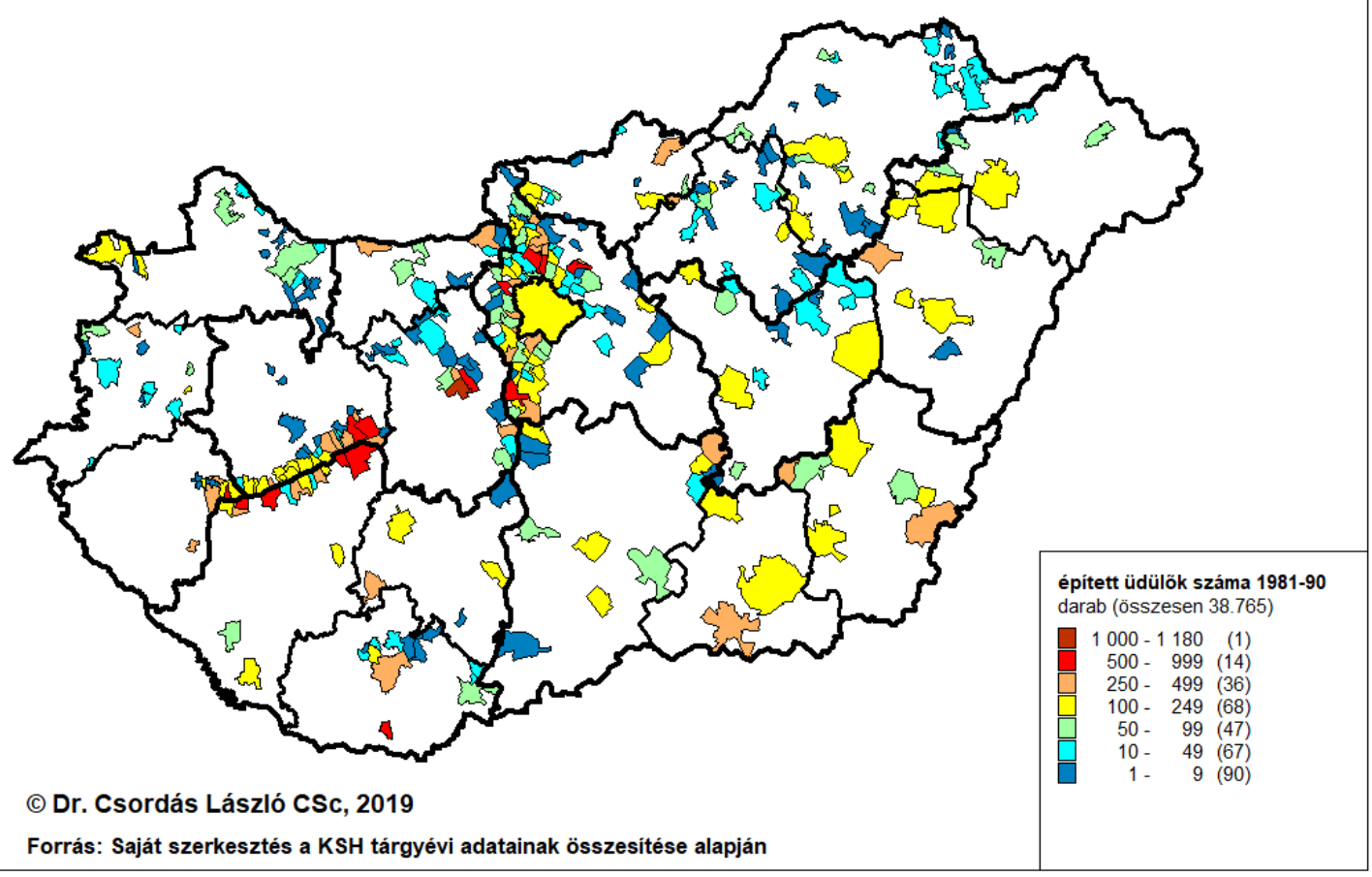

3. ábra: Az üdülőépités településenkénti alakulása Magyarországon, 1981-1990

Forrás: Saját szerkesztés a KSH tárgyévi adatainak összesitése alapján 
1. Táblázat. Az épitett üdülök száma, az üdülöépitésben érintett települések magyarországi száma, valamint az országos és az alföldi rangsorban első helyen végzett településeken az adott évben kialakított üdülök száma, az alföldinél az országos helyezéssel, 1981-2015

\begin{tabular}{|c|c|c|c|c|}
\hline Évek & $\begin{array}{c}\text { épített } \\
\text { üdülök } \\
\text { száma, } \\
\text { db }\end{array}$ & $\begin{array}{l}\text { érintett } \\
\text { telepü- } \\
\text { lések } \\
\text { száma }\end{array}$ & $\begin{array}{l}\text { az országban az } 1 . \\
\text { helyen végzett } \\
\text { település, a kialakitott } \\
\text { üdülök számával, } d b\end{array}$ & $\begin{array}{c}\text { az Alföldön az 1. helyen végzett } \\
\text { település, a kialakitott üdülök számával, } \\
\text { db, valamint (zárójelben az országos } \\
\text { rangsorban elfoglalt helyével) }\end{array}$ \\
\hline 1981 & 4675 & 214 & Siófok - 172 & Tiszakécske - 68 (13.) \\
\hline 1982 & 4554 & 218 & Siófok - 182 & Doboz - 44 (27.) \\
\hline 1983 & 4427 & 224 & Siófok - 224 & Nyíregyháza - 34 (42.) \\
\hline 1984 & 4536 & 226 & Boglárlelle - 164 & Tiszacsege -61 (15.) \\
\hline 1985 & 3527 & 228 & Harkány - 155 & Gyula - 104 (3.)! \\
\hline 1986 & 3458 & 223 & Gárdony - 219 & Doboz - $36(25)$. \\
\hline 1987 & 5206 & 240 & Gárdony - 251 & Gyula - 116 (6.)! \\
\hline 1988 & 3295 & 236 & Gárdony - 132 & Tiszacsege -55 (10.) \\
\hline 1989 & 2466 & 221 & Gárdony - 110 & Tiszavasvári - 89 (2.)! \\
\hline 1990 & 2621 & 224 & Harkány - 133 & Gyula - 109 (2.)! \\
\hline 1991 & 1753 & 204 & Gárdony - 58 & Tiszakécske - 22 (15.) \\
\hline 1992 & 2081 & 233 & Szentendre - 107 & Békésszentandrás - 33 (8.)! \\
\hline 1993 & 1654 & 221 & Sukoró - 42 & Abádszalók - 38 (3.) ! \\
\hline 1994 & 1541 & 215 & Szigetszentmiklós - 42 & Tiszacsege - $23(12-13)$. \\
\hline 1995 & 1354 & 216 & Orfü - 54 & Békésszentandrás - 33 (3.)! \\
\hline 1996 & 1260 & 204 & Kiskunmajsa - 56 & Kiskunmajsa - 56 (1.)! \\
\hline 1997 & 1466 & 227 & Balatonkenese -127 & Vásárosnamény - 44 (2.)! \\
\hline 1998 & 985 & 185 & Várgesztes - 46 & Tiszavasvári - 46 (1-2.)! \\
\hline 1999 & 833 & 199 & Kiskunmajsa - 27 & Kiskunmajsa - 27 (1.)! \\
\hline 2000 & 1006 & 197 & Ráckeve - 70 & Gyomaendrőd - 19 (10-11.) \\
\hline 2001 & 1128 & 196 & Hévíz - 71 & Abádszalók - 37 (7.) ! \\
\hline 2002 & 894 & 202 & Balatonkenese - 28 & Vásárosnamény - 18 (8.)! \\
\hline 2003 & 911 & 195 & Ráckeve - 40 & Szolnok - 21 (7-9.)! \\
\hline 2004 & 789 & 180 & Bük - 34 & Szolnok - 33 (2.)! \\
\hline 2005 & 971 & 183 & Zalakaros - 112 & Szolnok - 17 (7-8.)! \\
\hline 2006 & 836 & 170 & Zalakaros - 125 & Szolnok - 14 (7-10.)! \\
\hline 2007 & 782 & 159 & Budapest -127 & Tiszakécske - 19 (5-6.)! \\
\hline 2008 & 708 & 176 & Balatonőszöd - 74 & Gyomaendrőd - 12 (7-9.)! \\
\hline 2009 & 508 & 151 & Szentendre -43 & Szolnok - 14 (3.)! \\
\hline 2010 & 806 & 169 & Budapest -104 & Szolnok - 8 (16-17.) \\
\hline 2011 & 583 & 138 & Budapest -120 & Hajdúszoboszló - 15 (4.)! \\
\hline 2012 & 534 & 140 & Siófok - 116 & Hajdúszoboszló - 19 (3.)! \\
\hline 2013 & 314 & 137 & Szentendre -15 & Békésszentandrás - 12 (2-3.)! \\
\hline 2014 & 297 & 112 & Szántód - 33 & Szolnok - $12(4) !$. \\
\hline 2015 & 282 & 126 & Szentendre -17 & Szolnok - 8 (4.)! \\
\hline
\end{tabular}




\section{4. ábra: Az üdülõépítés településenkénti alakulása Magyarországon, 1991-2015}

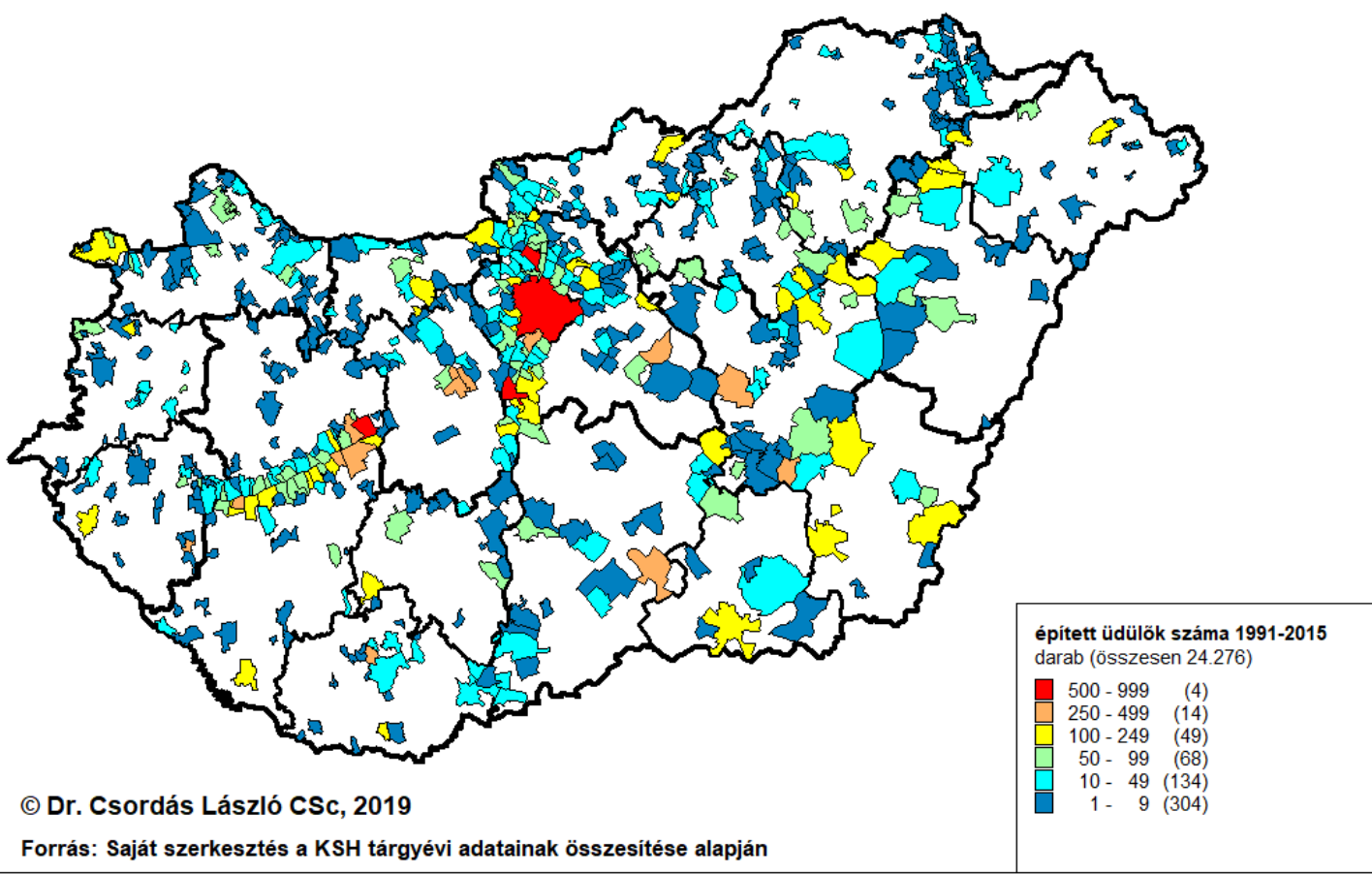

4. ábra: Az üdülőépités településenkénti alakulása Magyarországon, 1991-2015

Forrás: Saját szerkesztés a KSH tárgyévi adatainak összesítése alapján

A 2000-es évek első felében a két legismertebb nyugat-magyarországi gyógyüdülös hely, Hévíz (2001) és Bük (2004), majd 2005-2006-ban Zalakaros vezette a legtöbb nyaralót építő települések listáját. Egy-egy évben a 2.-3. helyen feltűntek távoli, új települések is a Tisza és a Tiszató mellöl (Vásárosnamény 1997, Tiszavasvári 1998, Sarud 2001), vagy a nyugati határszélröl is (Velem 2002). A 2003 utáni időszakban egyre többször bukkant fel eleinte 3., majd 2., 2007-töl első helyen is Budapest $(2007,2010,2011)$ és Szentendre $(2009,2013,2015)$. Nem volt olyan év 2003 után, hogy közülük az egyik, de 2007-2008-ban, 2010-2011-ben, 2014-ben mindkettő benne ne lett volna az első három legtöbb nyaralóépületet kialakító településcsoportban, ezen belül Szentendre 2006-2015 között mindig az első három település között volt. Mindez jelentősen hozzájárult ahhoz, hogy az 1991-2015 közötti negyedszázadban a Magyarországon felépített 24276 nyaralóból a legtöbbet Szentendrén (724 db) és Budapesten (647 db) alakították ki.

Az ezredfordulót követően 2002-2015 között - 2007 kivételével - Szolnok mindig felkerült a képzeletbeli alföldi dobogóra, ezen belül 2003-2006 között és 2014-2015-ben alföldi szinten az első helyen végzett, s ezzel országosan is a legjobb 10 közé került. Nem csodálkozhatunk ezek után, ha az 1991-2015 közötti időszak legtöbb felépült nyaralóépületével éppen Szolnok lett az első település az Alföldön. A 2000 utáni időszak elején Vásárosnamény (2002-2003), majd Gyomaendrőd (20062008 és 2013-2015), Orosháza (2010-2011) és Hajdúszoboszló (2011-2012) tudott több éven keresztül csatlakozni Szolnokhoz. Az országos tendenciáknak megfelelően a 2010 utáni időszakban már sokszor 10-nél kevesebb felépített nyaraló is elégséges volt az alföldi "dobogós" helyezéshez és érdekes módon ezzel még az országos rangsor első öt helyére is bekerültek.

Néhány érdekes dolog is megfigyelhető: az 1991-2004 közötti időszakban az első helyezésekhez - két év, 1992 (Szentendre 107 db) és 1997 (Balatonkenese 127 db) kivételével már kevesebb, mint 100 felépített üdülő is elég volt. Az utolsó tíz évben ugyanakkor a csökkenő országos kialakítás ellenére 2005-2006-ban Zalakaroson, 2007-ben Budapesten, majd 2010-11-ben ugyancsak Budapesten, 2012-ben pedig Siófokon 100 fölé került a felhúzott nyaralók száma. Ezekben az években az első három helyezett településen a Magyarországon felépített nyaralók egyharmadát-egynegyedét hozták létre, tehát a koncentráció fokozódott. 
Azon települések száma, amelyekben évente legalább 1 nyaralót kialakítottak 1991-1998 között még 200 felett volt, ám utána - 2002 kivételével - mindig elmaradt ettől, mélypontját 2014ben 112 településsel érte el. A vizsgált időszak végén, 2015-ben az országban kialakított üdülőépületek száma 282-re csökkent, amit 126 településen építettek fel: Szentendre 17 épülettel végzett az első helyen, ám a 3 . helyen álló Balatonmáriafürdőn már csak 8 nyaralóépületet létesítettek. Korábban soha nem volt példa arra, hogy ilyen alacsony értékkel felkerülhetett volna a képzeletbeli dobogóra egy település.

A 3. és a 4. ábra alapján az is megállapítható, hogy jelentős területi diffúzió mutatható ki a szabadidő-lakások terjedésében: az 1981-1990 közötti időszakban csak minden 9., míg 1991-2015 között minden 5. hazai település bekapcsolódott legalább egy évben ebbe a folyamatba, így fokozatosan és egyre távolabbi helyeken is megjelentek. Nagyon sok helységben, a teljes állomány felében csak kevesebb, mint 10 nyaralót alakítottak ki 1991-2015 között. A legfelső, 1000-nél több nyaralót felépített kategóriába már nem került egyetlen település sem, és jelentősen, a rendszerváltoztatás elötti évtizedhez képest 14-röl 4-re csökkent az 500-999 közötti, és 36-ról 14-re a 250-499 közötti felépített üdülőkkel rendelkező települések száma az utóbbi negyedszázadban. Ez azt jelenti, hogy míg korábban, 1981-1990 között a szabadidő-lakás építéssel jellemezhető települések közül 250-nél több nyaralót minden 6-7. helységben alakítottak ki, addig az azt követő negyedszázadban ez már csak minden 33. településre volt jellemzö.

Az első három helyezett (Szántód, Szentendre, Budapest) településen 2014-ben még 76 nyaralóépületet húztak fel, ám egy évvel később (Szentendrén, Balatonfüreden és Balatonmáriafürdőn) együttesen ennek csak alig több mint a felét, 39 darabot. Amennyiben ezt az 1981. évihez hasonlítjuk, akkor ott a három Somogy megyei településen (Siófokon, Fonyódon és Zamárdiban) 496 üdülőépületet emeltek, azaz közel 13-szor annyit, mint a teljes vizsgált időszak utolsó évében (2015-ben) az első három helyen végzett településen együttesen. $A z$ arányok ugyanakkor hasonlóak voltak, hiszen az első három település 1981-ben az országban felépített nyaralók 10,6 \%-át adta, 2015-ben pedig a 13,8 \%-át tette ki.

\section{4. Összegzés, következtetések}

A magánüdülök száma a Népszámlálás üdülö-összeírása szerint 2001-ben meghaladta a negyedmilliót, a legtöbb épület a Balaton és a Velencei-tó környékén valamint Pest megyében, a főváros és agglomerációjában található, mivel az elmúlt 35 évben - és különösen azt megelözően - itt építettek fel nagyon sok szabadidö-lakást. A nagyvárosokban és környékükön a zártkertekben kialakított hétvégi házak szerepe is meghatározó. Jelentőségüket az adja, hogy az üdülökben található féröhelyek száma többszörösét teszi ki a kereskedelmi szálláshelyeken lévő ágyak számának, és ennek következtében a hazai és részben a külföldi vendégek szabadidö-eltöltésében, vendégéjszakázásaiban nagy szerepet játszottak korábban és napjainkban is.

Hazánkban a vizsgált időszakban, azaz 1980 után létrehozott üdülök száma a KSH településenkénti adatai szerint meghaladja a 63 ezret, melyböl csak 10 ezer köthető a hat alföldi megyéhez. Számuk országosan az 1980-as évek eleji négyezres szintről indult, s a külső hatásokat követő jelentősebb ingadozásokkal egészen 1988-ig e fölött maradt. Az adószabályoktól (SZJA és az ÁFA) és az elszabaduló áremelkedésektől való félelmek miatt a legtöbb nyaralót 1987-ben alakították ki. Az azt követő évtől előbb a világútlevél bevezetése, majd a kiutaztató turisztikai vállalkozások beindulása, később a társadalmi-gazdasági változások miatt jelentős visszaesés következett be, így 1991-re az 1987. évi érték mintegy egyharmadára esett az épített nyaralóépületek száma országosan és az Alföldön is. A kialakított üdülök száma a '90-es években tovább feleződött, az ezredforduló után már az ezret (az Alföldön a 200-at) sem érte el, 2013-2015 között pedig az induló szint kevesebb, mint egytizedére, kb. 300-ra csökkent.

A legtöbb üdülőt 1981 óta - két évet kivéve - mindig Pest megyében építették fel, amit jelentősen lemaradva Somogy és Veszprém, illetve 1986-90 között Fejér megye követett. Településenként vizsgálva a legtöbb nyaralót 1981-90 között Gárdony, Siófok, Balatonkenese, 1991-töl napjainkig pedig Szentendre, Budapest és Ráckeve területén alakították ki, tehát 
fokozatosan eltolódott a Balaton-parttól Fejér, majd Pest megyébe, a föváros közelébe az üdülőépítések súlypontja.

Az Alföldön Bács-Kiskun megyétöl elöbb Békés, majd az ezredforduló óta - 2006 és 2008 kivételével - minden évben Jász-Nagykun-Szolnok megye hódította el az elsőséget, ami a Tisza, a Tisza-tó és a gyógy- és termálfürdők felértékelődését jelzi. Települési szinten a rendszerváltást megelőző évtizedben Gyula, Tiszakécske, Békésszentandrás és Tiszacsege, az azt követő negyedszázadban pedig Szolnok, Kiskunmajsa, Békésszentandrás és Abádszalók területén alakították ki a legtöbb szabadidö-lakást.

Az üdülőépítési folyamat hosszabb távon lényegesen megváltoztathatja az érintett települések térbeli rendszerét, azok morfológiáját, funkcionális tagolódását, infrastruktúráját, földhasznosítását, az ott lakó népesség társadalmi és demográfiai stb. viszonyait is. Jelentős változást hozhat elsősorban a fogadóterületek társadalmában és életmódjában is.

\section{Köszönetnyilvánítás}

Köszönettel tartozunk a kutatás támogatásáért, amely az EFOP-3.6.1-16-2016-00006 „A kutatási potenciál fejlesztése és bővítése a Neumann János Egyetemen" pályázat keretében valósult meg. A projekt a Magyar Állam és az Európai Unió támogatásával, az Európai Szociális Alap társfinanszírozásával, a Széchenyi 2020 program keretében valósul meg.

\section{Irodalomjegyzék}

[1] Baár L-né -Gratzl F. (2004): 2001. évi népszámlálás: 15. Az üdülök adatai. - KSH, Budapest. 147 p.

[2] Coppock, J. T. (ed.) (1977): Second Homes: Curse or Blessing. - Pergamon, Oxford. Geogr. Series 194 p.

[3] Csatári B. - Csordás L. (1991): Tanya és rekreáció az Alföldön. - In. Rakonczai J. (szerk.): Az Alföld jelene és jövője. (Tisza-klub füzetei I.) pp. 31-34.

[4] Csordás L. (1995): Szabadidő-lakások az Alföldön. - Kandidátusi értekezés. p. 154. + p. 260 melléklet + 275 térkép

[5] Csordás L. (1999): Second homes in Hungary. - In. Duró A. (ed.) Spatial Research in Support of the European Integration. MTA RKK, Pécs. (Discussion Papers, Special) pp. 145-160.

[6] Csordás L. (2007a): A második otthonok definíciója és a jelenség térbeli hatásai. - In. Kovács Cs. - Pál V. (szerk.): A társadalmi földrajz világai. SZTE Gazdaság- és Társadalomföldrajzi Tanszék, Szeged. pp. 117-131.

[7] Csordás L. (2007b): A magánüdülők építése és állománya Magyarországon. In. Szónokyné Ancsin G., Pál V., Karancsi Z (szerk.) A határok kutatója: tanulmánykötet Pál Ágnes tiszteletére. 286 p. Szeged; Szabadka: Magyarságkutató Tudományos Társaság, 2007. pp. 81-89.

[8] Enyedi Gy. (1988): A városnövekedés szakaszai. - Akadémiai Kiadó, Budapest. p. 115

[9] Kowalczyk, A. (1994): Geograficzno-spoleczne problemy zjawiska "drugich domów". - Warszawa. 178 p.

[10] Martonné Erdős K. (1990): Az egyéni rekreáció lehetőségei és megvalósulásai Miskolc környékén. Kandidátusi értekezés. Kézirat. KLTE Debrecen. 158 p.

[11] Michalkó G. (2007): Magyarország modern turizmusföldrajza. - Dialóg Campus Kiadó, Pécs-Budapest. 287 p.

[12] Ruppert, K. (1973): Der Zweitwohnsitz im Freizeitraum. - Berichte zur Raumforschung und Raumplanung, 17. 4. pp. 3-8.

[13] Ruppert, K. (1994): Zweitwohnsitze - Wohnstandortsspaltung als Bestandteil der Raumorganisation. - Manuskript. p. 5

[14] Timár J. (1994): Az alföldi szuburbanizáció néhány sajátossága. - Alföldi Tanulmányok. 15. pp. 217-232. 